\title{
A QUALIDADE DA EDUCAÇ̃̃O INFANTIL COMO OBJETO DE ANÁLISE NAS DECISÕES JUDICIAIS
}

\author{
BARBARA CRISTINA HANAUER TAPOROSKY ${ }^{1}$ * \\ ORCID: https://orcid.org/0000-0002-8251-6005 \\ ADRIANA APARECIDA DRAGONE SILVEIRA ${ }^{1 \text { ** }}$ \\ ORCID: https://orcid.org/0000-0001-6022-627X
}

RESUMO: Este artigo objetiva analisar as decisões proferidas pelos 27 Tribunais de Justiça do Brasil em ações coletivas nas quais se discute o direito à educação infantil, visando identificar se e de que maneira a qualidade da educação infantil é discutida pelo sistema de justiça. Identificaram-se 107 decisões que foram organizadas em 10 categorias: proximidade da residência e transporte público; apoio técnico e financeiro dos estados; infraestrutura; construção; profissionais; número de crianças por adulto, por turma e dimensão mínima; jornada e carga horária; currículo; e outras decisões, que não se encaixam nas demais categorias; e negativa do acesso fundamentada na redução da qualidade da educação infantil. Após realizada a análise do conteúdo das decisões, concluiu-se que os Tribunais têm analisado condições de oferta, mas ainda de forma restrita, não sendo possível identificar uma judicialização relevante de condições de qualidade da educação infantil.

Palavras-chave: Direito à educação; Educação infantil; Qualidade da educação; Judicialização da educação; Políticas educacionais.

\footnotetext{
${ }^{1}$ Universidade Federal do Paraná (UFPR), Curitiba, PR, Brasil.

"Mestre e doutoranda em educação pela Universidade Federal do Paraná (UFPR).

E-mail:< barbara86ha@yahoo.com.br $>$.

"* Doutora em Educação pela Universidade de São Paulo (USP). Professora do Departamento de Planejamento e Administração Escolar da Universidade Federal do Paraná (UFPR).

E-mail:< adrianadragone@yahoo.com.br >
} 


\section{THE QUALITY OF EARLY CHILDHOOD EDUCATION AS ANALYSIS OBJECT IN JUDICIAL DECISIONS}

ABSTRACT: This article analyzes the decisions handed down by the 27 Courts of Justice of Brazil in collective actions in which the right to an early childhood education is discussed, in order to identify if and in what way the quality of child education is discussed. It was identified 107 decisions that were organized in 10 categories: proximity of the residence and public transportation; technical and financial support from the states; infrastructure; construction; professionals; number of children per adult, per class and minimum size; working hours and workload; curriculum; other decisions that do not fit into the other categories; and negative access based on reducing the quality of early childhood education. After analyzing the decisions' content, it was concluded that the Courts have analyzed supply conditions, but still in a restricted way, and it is not possible to identify a relevant judicialization of quality conditions of early childhood education.

Keywords: Right to education; Early childhood education; Judicialization of education; Quality of education; Educational policies.

\section{INTRODUĈ̣̃O}

Há um campo de pesquisa relacionado às políticas educacionais que vêm crescendo nos últimos anos, que envolve as análises do Poder Judiciário e do sistema de justiça como atores de promoção do direito à educação. Machado e Oliveira (2001) e Silveira (2008) já apontaram a importância de estímulo de pesquisas envolvendo essa temática.

Dentre elas, há aquelas que discutem o papel do Ministério Público e dos Tribunais na garantia do direito à educação, os instrumentos processuais para sua garantia, a caracterização do direito à educação como direito público subjetivo (SILVEIRA, 2008) e, ainda, aquelas que se voltam à análise das jurisprudências, ou do posicionamento dos Tribunais sobre as questões educacionais (CURY; FERREIRA, 2010), que compõem o campo das políticas educacionais (TELLO, 2005). Encontram especial relevância na medida em que as decisões proferidas pelo Poder Judiciário interferem nas políticas educacionais e, muitas vezes, deslocam para o sistema de justiça decisões que originalmente competiam aos Poderes Executivo e Legislativo, fenômeno designado de judicialização (BARROSO, 2009; SILVEIRA, 2015). Sendo assim, afigura-se importante fomentar o debate a respeito das decisões que são proferidas pelo Poder Judiciário e de seu conteúdo.

Dentre estas pesquisas, tem crescido o número daquelas que se dedicam à garantia do direito à educação infantil (EI) pelo sistema de justiça (SILVEIRA, 2008; MARINHO, 2009; SILVEIRA, 2010; 
RIZZI; XIMENES, 2010; XIMENES; GRINKRAUT, 2014), uma vez que há um grande número de ações judiciais visando à obtenção de vagas nesta etapa da educação, de forma que sua expansão se dá, muitas vezes, pela via judicial (SILVEIRA, 2013).

O presente artigo insere-se neste campo de pesquisa, integrando o projeto "Efeitos da atuação do sistema de justiça no direito à educação infantil: um estudo da judicialização da política educacional em três estados brasileiros", financiada pelo Conselho Nacional de Desenvolvimento Científico e Tecnológico (CNPq), uma vez que tem como objetivo verificar o conteúdo das decisões proferidas pelos Tribunais de Justiça do Brasil em ações coletivas que discutem o direito à EI, para averiguar se e de que maneira a qualidade da oferta da EI é discutida pelo sistema de justiça. Para tanto, visando demonstrar a relevância da presente pesquisa, em um primeiro momento será discutida a ampliação do acesso à EI por meio do sistema de justiça e suas implicações para a qualidade das condições de oferta, bem como a necessidade do reconhecimento do direito à educação enquanto um direito coletivo. Na sequência, serão apresentados os dados da pesquisa e seus resultados, indicando o que foi encontrado nas decisões proferidas pelos 27 Tribunais de Justiça do Brasil em ações coletivas nas quais se discute o direito à educação infantil e que remetem à qualidade da oferta da EI, cujo conteúdo será discutido em categorias previamente elaboradas e que serão oportunamente indicadas.

\section{A AMPLIACCÃO DO ACESSO À EI POR MEIO DO SISTEMA DE JUSTIÇA E SUAS IMPLICAÇÕ̃ES NA QUALIDADE DA OFERTA}

A ampliação do acesso à educação básica no Brasil nas últimas três décadas é um grande avanço para a efetivação do direito à educação, (BEISEGEL, 2006; OLIVEIRA, 2006). Contudo, de acordo com Campos e Haddad (2006), a expansão sem que se garantissem condições de qualidade acabou por, especialmente para as classes populares, ofertar escolas com condições de funcionamento questionáveis, com prédios com infraestrutura precária, sem quadro de pessoal completo e, muitas vezes, pessoal sem qualificação. $\mathrm{O}$ acesso, portanto, não é suficiente para a garantia do direito: é necessário que a oferta se dê com qualidade (LIBERATI, 2004), uma vez que, nos termos do art. 208, $§ 2^{\circ}$ da Constituição Federal (CF/88), a oferta sem qualidade constitui-se em oferta irregular (OLIVEIRA, 2006; CABRAL, 2008). 
Esses problemas marcaram e marcam, também, o atendimento às crianças pequenas na EI, aliados à necessidade de democratização do acesso e da exigência da qualidade enquanto direito (CAMPOS; HADDAD, 2006). Se, muitas vezes, a ampliação do acesso na EI dáse por meio de demandas judiciais (SILVEIRA, 2013), decisões que determinam abertura de vagas sem considerar um padrão mínimo de qualidade poderiam colaborar com este cenário, ainda que assegurem uma importante dimensão deste direito.

Isto é ainda mais visível no caso das ações coletivas. No âmbito do direito processual, as requisições de vagas podem se dar por duas principais vias: a via da tutela individual ou a via da tutela coletiva. Por meio da tutela individual um único interessado requer, em seu interesse individual, a requisição da vaga para si; já por meio das ações coletivas o direito é exigido em favor de um grande número de titulares, por legitimados elencados na legislação, como o Ministério Público, organizações da sociedade civil, sindicatos, partidos, etc.

Os direitos sociais e, portanto, o direito à educação, devem ser considerados enquanto direitos de titularidade coletiva, uma vez que são fruíveis e exigíveis coletivamente, mesmo que cada pessoa possa ser dele considerada titular individualmente (BOBBIO, 1992; LOPES, 2002). Dessa maneira, a efetividade desse direito é melhor atendida pela via coletiva, visando dar uma solução homogênea a todos que dele são titulares (ARAÚJO, 2013), evitando que se conceda o direito individual apenas ao indivíduo que a requer, em detrimento dos demais titulares que também aguardam a sua efetivação (SILVEIRA, 2013). No caso específico da EI, ademais, a norma inserta no art. 208, III, e $\$ 1^{\circ}$ do Estatuto da Criança e do Adolescente (ECA) indica a possibilidade de via processual coletiva para sua proteção (BRASIL, 1990), que se dá mediante a utilização de instrumentos processuais específicos - como, por exemplo, a ação civil pública, ${ }^{1}$ o mandado de segurança coletivo, ${ }^{2}$ o mandado de injunção, ${ }^{3}$ entre outros - pelos atores que possuem legitimidade para ajuizamento dessas demandas, conforme disciplina legal.

Desta maneira, decisões proferidas nestas demandas coletivas têm, em tese, o condão de causar maior interferência nas políticas educacionais dos municípios, especialmente quando a determinação de ampliação vem desacompanhada de questões relacionadas à qualidade da oferta. Contudo, não se pode deixar de observar que as demandas individuais, quando propostas em grande número, também têm a capacidade de causar impactos nas políticas educacionais, como já apontado por Silva (2016). 
$\mathrm{Na}$ garantia do direito à educação pela via do Sistema de justiça, além do desafio das requisições coletivas versus individuais, Silveira (2008, p. 550) aponta para a dificuldade de tipificação do que seria "qualidade de ensino", sendo esses "portanto, menos passíveis de exigibilidade judicial". Entendimento este abordado por Oliveira e Araújo (2005) em artigo que discute a qualidade da educação como uma nova dimensão da luta pelo direito à educação, no qual indicam a necessidade de se construir um padrão de qualidade passível de ser exigido perante o sistema de justiça.

Contudo, o trabalho de Ximenes (2014) aponta que a garantia do padrão de qualidade, por se tratar de um princípio constitucional, é dotada de justiciabilidade - que é a possibilidade de ser exigida perante o sistema de justiça (PANNUNZIO, 2009). Este autor indica que considerar a qualidade um princípio de direito "determina ao Estado a adoção de medidas, positivas e negativas, com o máximo de recursos disponíveis e progressivamente, com a finalidade de assegurar o exercício, por todos, da máxima qualidade na escolarização" (XIMENES, 2014, p. 234). Essa compreensão não significa necessariamente que todos os elementos que compõem seu conteúdo jurídico poderão ou deverão ser exigidos em juízo, mas que se afigura relevante que o Poder Judiciário, em determinados casos, para cumprimento de sua função constitucional, atente às condições de qualidade positivadas no ordenamento jurídico brasileiro, no julgamento de demandas que envolvam o direito à educação.

Partindo desses pressupostos é que se buscou analisar decisões proferidas pelos 27 Tribunais de Justiça do Brasil, nas quais se exigia em ações coletivas o direito à EI, a fim de identificar se a qualidade da oferta da EI era, de alguma maneira, abordada nestes julgados. Foram selecionadas as ações coletivas no entendimento de que essas são mecanismos mais adequados para acionar o controle judicial envolvendo políticas públicas, tendo efeitos de maior abrangência, favorecendo a isonomia.

\section{PERCURSOS METODOLÓGICOS}

A coleta das decisões foi realizada nos 27 Tribunais de Justiça do Brasil, mediante busca de jurisprudência por meio dos descritores "creche", "pré-escola" e "educação infantil". Foram coletadas para análise decisões proferidas entre outubro de 2005 - que é a data na qual o Supremo Tribunal Federal (STF) reconheceu que a oferta da 
EI constitui-se em um dever do Estado (BRASIL, 2005) - e julho de 2016. Por meio da leitura das ementas, selecionaram-se as decisões proferidas em ações coletivas nas quais se exigia o direito à EI, mas excluindo aquelas que tratavam apenas do acesso. Também não foram consideradas decisões que se referiam apenas ao atendimento ininterrupto nos períodos de férias e recesso escolar, adaptação de prédios escolares exclusivamente para acesso às pessoas com deficiência ou execuções de termos de ajustamento de conduta ou cumprimento de sentenças, assuntos estes que podem constituir objeto de análise de pesquisas futuras.

Foi realizada, então, a leitura das decisões e a seleção daquelas que tinham relação com o objeto da pesquisa. Após, foram criadas categorias para sua análise, a partir das condições de oferta nelas discutidas: proximidade da residência e transporte público; apoio técnico e financeiro dos estados; infraestrutura; construção; profissionais; número de crianças por adulto, por turma e dimensão mínima; jornada e carga horária; currículo; outras decisões, que irá reunir aquelas que trabalham condições de oferta específicas e que não se encaixam nas demais categorias; e negativa do acesso fundamentada na redução da qualidade da EI.

Desta forma, a seção a seguir será destinada a apresentar os achados, bem como os principais aspectos discutidos pelos Tribunais de Justiça do Brasil em cada uma das categorias criadas.

\section{RESULTADOS}

Foram encontradas 107 decisões que discutem, em determinada medida, questões relacionadas à qualidade da oferta da EI, organizadas em 10 categorias, como anteriormente indicado. O gráfico 1 a seguir demonstra a quantidade de decisões analisada em cada uma das categorias. É necessário esclarecer que, por vezes, uma única decisão encaixa-se em mais de uma categoria, por discutir condições de oferta diversas. 
GRÁFICO 1. Quantidade de decisões segundo as condições de oferta da El, proferidas em ações coletivas pelos Tribunais de Justiça do Brasil (2005 -2016)

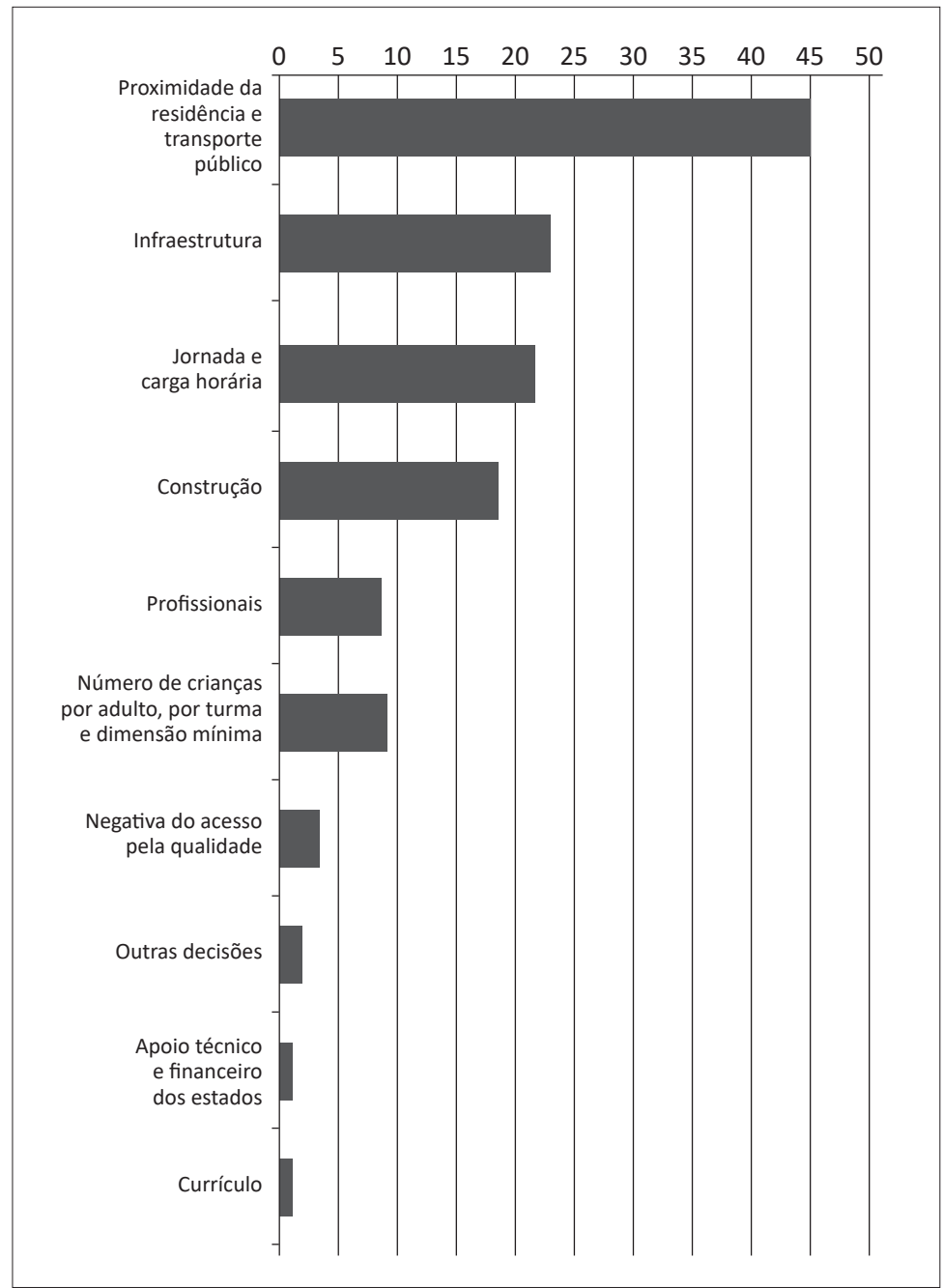

Fonte: Elaborado com base em pesquisa realizada nos Tribunais de Justiça do Brasil (2017).

Embora a pesquisa tenha sido realizada em todos os Tribunais de Justiça do país, foram encontradas decisões que discutem alguma condição de oferta apenas nos Tribunais de Justiça do Acre (TJAC), Pará (TJPA), Rondônia (TJRO), Tocantins (TJTO), Alagoas (TJAL), Maranhão (TJMA), Rio Grande do Norte (TJRN), Sergipe (TJSE), Goiás (TJGO), Mato Grosso (TJMT), Mato Grosso do Sul (TJMS), Espírito Santo (TJES), Minas Gerais (TJMG), Rio de Janeiro (TJRJ), São Paulo (TJSP), Paraná (TJPR), Rio Grande do Sul (TJRS) e Santa Catarina (TJSC). 
Os Tribunais de Justiça do Amapá (TJAP), Amazonas (TJAM), Bahia (TJBA), Paraíba (TJPB), contam, cada um, com uma decisão proferida em ações coletivas nas quais se exige o direito à EI. Contudo, nenhuma destas decisões discute questões relativas à qualidade da oferta. Por sua vez, em relação aos demais Tribunais de Justiça do Brasil, quais sejam os de Roraima (TJRO), Ceará (TJCE), Pernambuco (TJPE), Piauí (TJPI) e Distrito Federal e Territórios (TJDFT), não foi possível encontrar nenhuma decisão proferida em ações coletivas relacionadas à temática.

Estes achados permitem questionar os motivos que geram um maior número de demandas sobre a temática nos diferentes estados da federação, bem como se, neles, a exigibilidade judicial deste direito estaria adstrita a demandas individuais ou se o direito não é requisitado pela via judicial, o que poderia compor o objeto de pesquisas futuras sobre o litígio envolvendo a EI.

Antes de adentrar a análise do conteúdo das decisões proferidas em cada uma das categorias é importante ressaltar que qualquer decisão do Poder Judiciário precisa ser devidamente fundamentada, nos termos do artigo 11 do Código de Processo Civil (BRASIL, 2015). Scaff e Pinto (2016), ao realizarem uma análise das decisões proferidas pelo STF para a garantia do direito à educação de crianças e adolescentes, indicam os principais fundamentos enfrentados pela corte para a concessão do direito, quais sejam o reconhecimento do direito à educação (incluindo a EI) como direito fundamental social plenamente exigível; a possibilidade do Poder Judiciário analisar políticas públicas nos casos nos quais os demais poderes não atuaram de acordo com os preceitos constitucionais; e, ainda, a impossibilidade de negativa do direito apenas mediante a alegação de escassez de recursos (teoria da reserva do possível). As autoras esclarecem que a maior parte dessas decisões se refere à concessão de vagas na EI por meio de demandas individuais, sendo que de sua análise é possível extrair o posicionamento favorável da corte em relação à sua efetividade.

Da análise das decisões selecionadas para este artigo, verificase que, em grande parte, limitam-se a discutir essas mesmas questões apresentadas por Scaff e Pinto (2016). Apresentam o direito à educação como direito social, elencando as previsões constantes na CF/88, ECA e Lei de Diretrizes e Bases da Educação Nacional (LDB) aplicáveis à garantia do direito à EI; discutem, ainda, questões atinentes aos princípios da dignidade da pessoa humana e da separação dos poderes, a garantia do mínimo existencial e a teoria da reserva do possível. Em geral são essas as questões discutidas nas 
ações em que se exige a EI, como retratado, por exemplo, no trabalho de Silveira (2014). As fundamentações das decisões selecionadas neste trabalho não divergem desses achados. Desta forma, a apresentação do conteúdo das decisões será realizada dentro das categorias apresentadas, detendo-se àquelas que apresentem alguma peculiaridade em sua fundamentação, conforme se vê a seguir.

\section{PROXIMIDADE DA RESIDÊNCIA E TRANSPORTE PÚBLICO}

O ECA prevê, em seu artigo 53, V, que o direito à educação de crianças e adolescentes deve ser garantido mediante o acesso à escola pública próxima à sua residência (BRASIL, 1990). Essa previsão também consta no art. $4^{\circ}, \mathrm{X}$, da LDB, para todas as crianças a partir do dia em que completam quatro anos de idade (BRASIL, 1996). Já o art. 208, VII, da CF/88, prevê que o atendimento ao educando deve se dar mediante a oferta de transporte escolar (BRASIL, 1988). Portanto, essas condições de oferta já estão devidamente positivadas no ordenamento jurídico brasileiro. As Diretrizes Curriculares Nacionais para a EI também preveem que a oferta de vagas nessa etapa da educação deve se dar próximo à residência das crianças (BRASIL, 2010).

Há 44 decisões em que a oferta de vagas em EI próxima à residência das crianças ou do local de trabalho dos pais e/ou a questão do fornecimento do transporte público é discutida. Em grande parte dessas decisões, apenas consta a concessão do direito, sem que se faça, na fundamentação da decisão, qualquer referência a essas condições de oferta.

Contudo, algumas decisões acrescentam à sua fundamentação expressamente que compõe o direito à EI a oferta de vagas próximas à residência das crianças com base na $\mathrm{CF} / 88$, nos art. $4^{\circ}, \mathrm{X}$ e 11 da LDB, ou nos art. 53, V e 54, IV do ECA. Algumas decisões ainda deferem esta condição de oferta sob o fundamento de que oferta de vagas próxima à residência das crianças tem o condão de promover e estimular o acesso delas à educação.

Cabe destacar um julgado em que consta da fundamentação que a garantia da vaga próxima à residência da criança lhe assegura "o desenvolvimento harmonioso e sadio, o que não pode ser de forma alguma dificultado pela inércia do setor público, sob pena de vulneração a direito constitucional garantido e aos princípios da isonomia e da igualdade de condições” (MINAS GERAIS, 2012, p. 6-7). Em outro, determinou-se a matrícula de 42 crianças em unidades de EI em distância não superior a dois quilômetros de suas residências (SÃO PAULO, 2011). Este mesmo tribunal julgou caso no qual se determinou 
a abertura de vagas em três bairros específicos do município, que não contavam com unidades de EI (SÃO PAULO, 2015).

Há casos nos quais foi determinada a concessão de vagas próximas à residência das crianças ou, na impossibilidade, que fossem matriculadas em quaisquer unidades de EI do município mediante a oferta do serviço de transporte escolar, com base nos art. 208, VII e 227 da $\mathrm{CF} / 88$. As decisões ressaltaram que, oportunizar ao ente público a escolha entre a oferta da vaga próxima à residência ou a disponibilização do transporte, respeita a discricionariedade administrativa, já que o município decidirá a forma de cumprimento da decisão.

Mas também há casos nos quais esse direito é negado pelos tribunais. Entre os argumentos utilizados, há que o pedido realizado na ação coletiva é genérico e abstrato, de alcance indeterminado e cujo cumprimento seria de difícil ou incerta avaliação. Contudo, como já apontado anteriormente, o direito à EI, enquanto um direito social, seria melhor atendido coletivamente (BOBBIO, 1992; LOPES, 2002; SILVEIRA, 2013). Portanto, negar seu cumprimento sob este fundamento significa limitar a abrangência deste direito, não o reconhecendo como um direito de titularidade coletiva, uma vez que sua garantia só deveria se dar mediante a individualização de seus titulares.

Outro argumento para a negativa seria de que as normas da $\mathrm{CF} / 88$ que tratam do direito à educação seriam normas programáticas e, portanto, não exigíveis pelos cidadãos contra o Estado. Contudo, já é amplamente reconhecida a plena eficácia dos direitos sociais na literatura, como apontado por Abramovich (2005), Lopes (2002) e Ximenes (2014), entre outros autores. Piovesan (2012, p. 230) aponta que "a ideia da não acionabilidade dos direitos sociais é meramente ideológica e não científica. São eles autênticos e verdadeiros direitos fundamentais, acionáveis, exigíveis e demandam séria e responsável observância”.

Um último argumento encontrado como fundamento para a negativa nestas decisões é de que a concessão das medidas acarretaria um desequilíbrio econômico e financeiro ao município, gerando lesão a bens de interesse público e/ou que o ente não teria condições de realizar maiores investimentos na área. Entretanto, embora se reconheça que as decisões orçamentárias tratam-se de decisões políticas, Jacob (2013) já apontou que as mesmas precisam ser realizadas com base nos fins constitucionais, que norteiam as decisões administrativas do poder público. Tendo em vista que o direito à EI, enquanto um direito social, trata-se também de um direito fundamental, deve ser contemplado com prioridade nas opções políticas, inclusive orçamentárias (CANELA JUNIOR, 2013). 


\section{INFRAESTRUTURA}

As questões relacionadas à infraestrutura dos prédios da EI são extremamente amplas. Foram localizadas, segundo os critérios do presente trabalho, 23 decisões em que se discutiam aspectos relacionados às adaptações estruturais, equipamentos, mobiliários, entre outras.

Há algumas decisões em que foram mantidas as determinações de primeira instância, discutindo-se na fundamentação os argumentos gerais relacionados à concessão do direito à EI, sem adentrar ou especificar as questões relacionadas à infraestrutura. Em outros, para a concessão do direito a fundamentação foi realizada com base no art. 70 da LDB, que trata das despesas com manutenção e desenvolvimento do ensino, confirmando o dever do Estado em relação à manutenção e infraestrutura dos prédios que abrigam unidades de EI. Em um caso encontrou-se fundamento firmado em regulamentação municipal sobre o tema. Houve casos nos quais a fundamentação foi baseada no direito das crianças, profissionais e famílias frequentarem um ambiente seguro, saudável e confortável, sendo dever do Estado sua promoção. Dentre estes casos, há aqueles que se utilizam do princípio da dignidade da pessoa humana e que apontam esta questão como essencial para assegurar a permanência das crianças nesta etapa educacional. Ainda cabe destacar a ausência de uma regulamentação nacional sobre esse requisito de oferta da qualidade do atendimento educacional

Verifica-se, assim, que embora haja em certa medida preocupação com a infraestrutura das unidades de EI, não se verifica um aprofundamento da discussão a partir das necessidades das crianças (BRASIL, 1998), mas muito mais com questões relacionadas à segurança e salubridade dos prédios. Não se discutem aspectos relacionados a questões estéticas, de funcionabilidade ou ambientais, apontadas por Zabalza (2007) como essenciais para a promoção de uma EI de qualidade, o que permanece, portanto, no âmbito de discricionariedade do poder público, ou seja, para ser decidido pela administração pública quando da oferta desta etapa educacional.

Contudo, foram encontrados casos nos quais os pedidos relacionados à infraestrutura foram negados, sob o fundamento de que se configurariam em ingerência indevida do Poder Judiciário sobre o Poder Executivo e, portanto, feriria o princípio da separação de poderes, bem como que o deferimento do pedido poderia acarretar desequilíbrio nas contas do município.

Cabe salientar, entretanto, que a própria $\mathrm{CF} / 88$ prevê a possibilidade de controle judicial dos atos do Poder Executivo 
quando o mesmo dificulte ou impeça o pleno exercício de um direito fundamental, que é o caso do direito à EI (VICTOR, 2011). Se há lesão a direito fundamental, cabe ao Judiciário intervir sem que se configure ofensa ao princípio da separação dos poderes (CANELA JUNIOR, 2013), motivo pelo qual não pode este argumento ser suficiente a afastar a análise do Poder Judiciário de casos nos quais o direito à EI não é atendido adequadamente. Ainda assim há que se respeitar o poder de escolha do Poder Executivo em como cumprir este direito, abrindose espaço para a discricionariedade administrativa (SILVEIRA, 2013), o que precisa ocorrer observando-se os limites legais de escolha da solução ótima entre diversas possíveis (PIETRO, 2001).

\section{CONSTRUC̣ÃO}

Foram identificados 22 casos nos quais, em vez de se determinar a abertura de vagas, matrícula ou ampliação do atendimento, os tribunais determinaram a construção de unidades. Optou-se por selecionar tais decisões para a análise qualitativa, na medida em que, de alguma forma, o Judiciário está determinando obrigações que colaboram para a melhoria do atendimento. A construção amplia o número de vagas, demanda a contratação de novos profissionais, entre outras condições necessárias à EI de qualidade.

Em alguns casos, determina-se apenas a construção, sem indicar seus parâmetros. Nesses, a fundamentação da decisão remete ao direito à EI e aos demais fundamentos gerais ligados à questão, já abordados neste artigo. Há alguns casos nos quais se determina a construção das unidades em locais específicos no município.

Contudo, há outros casos em que as determinações das decisões são mais detalhadas, como um no qual se determinou que o município colocasse em funcionamento duas creches e duas pré-escolas, no prazo de quatro meses, situadas na zona urbana e rural, nos povoados mais populosos, com definição do número limite de crianças e equipadas com material pedagógico, de segurança, mobiliário, limpeza, equipe especializada em EI e demais requisitos legais (ALAGOAS, 2015). Consta, ainda, da decisão, que o funcionamento das unidades deveria se dar de acordo com o previsto no art. 31 da LDB, ou seja: avaliação mediante registro de desenvolvimento da criança, sem objetivo de promoção; carga horária mínima anual de 800 horas divididas em 200 dias letivos; atendimento de, no mínimo, 4 horas para o turno parcial e 7 horas para o turno integral; controle de frequência; e "expedição de documentação que permita atestar os processos de desenvolvimento e aprendizagem da criança" (BRASIL, 1996). 
Em outro caso se determinou a retomada de construção de duas unidades de EI, sendo que muitas dessas crianças estavam matriculadas em instituições sem infraestrutura adequada. O município foi condenado a viabilizar o funcionamento imediato das instituições "com material de expediente, mobiliário, brinquedos pedagógicos, merenda escolar, material de limpeza e demais itens necessários para o regular funcionamento" (RIO GRANDE DO NORTE, 2014, p. 2).

Não obstante, há casos no qual o requerimento de construção de creches é negado, sob o fundamento de que configura ingerência indevida do Poder Judiciário na Administração, por se tratar de ato discricionário. Integra o fundamento dessas decisões que cabe apenas ao Executivo a função de governo, com base no princípio da separação de poderes. Portanto, seria de sua responsabilidade a identificação e avaliação das necessidades sociais, com a apresentação e execução de suas soluções; assim, não seria permitido ao Judiciário a implementação de políticas públicas.

\section{PROFISSIONAIS}

Em relação aos profissionais que atuam na EI, há diferentes variáveis que influenciam para sua oferta com qualidade. A LDB prevê que há diversos profissionais que podem atuar na educação básica e, portanto, na EI, nos termos do art. 61: professores habilitados em nível médio ou superior para a docência na EI; trabalhadores da educação devidamente diplomados na área ou diplomas técnicos em área pedagógica ou afim. O art. 62 do mesmo diploma legal prevê como formação mínima para atuar na EI e nos cinco primeiros anos do ensino fundamental a obtida em nível médio, na modalidade normal (LDB, 1996).

Por sua vez, a lei $11.738 / 2008$ disciplina o piso salarial nacional: prevê que os professores com formação em nível médio, na modalidade normal, tenham como vencimento o piso salarial profissional nacional para jornadas de 40 horas (BRASIL, 2008).

Os parâmetros nacionais para qualidade na EI preceituam que a equipe de profissionais que deverá atuar nessa etapa da educação pode ser composta, além dos professores, por gestores e outros profissionais de apoio e de assessoria, visando o aperfeiçoamento profissional (BRASIL, 2006). No entanto, referido documento norteador não indica, por exemplo, a formação mínima necessária a esses profissionais.

Portanto, foram localizados nove casos nos quais, em determinada medida, discutem questões relacionadas aos profissionais que atuarão na EI. Assim como já indicado nas categorias anteriores, 
há casos em que os tribunais analisam alguma condição de oferta relacionada aos profissionais fundamentando-se no direito à EI de forma geral, como os demais argumentos já abordadas neste artigo. Tratam da abertura e/ou da nomeação de aprovados em concurso para professor de EI e/ou auxiliar de creche dentro do número de vagas previstas no certame e em quantidade suficiente a sanar o déficit existente, dentro do prazo de validade do concurso; de oferta da EI mediante a capacitação do corpo docente, ainda que sem maiores especificações de como deva se dar esta capacitação; da colocação em funcionamento de creches e pré-escolas, com equipe especializada em EI; da abertura de concurso público para contratação de professores de EI e para auxiliares de creche; da formação do corpo docente de acordo com os termos de norma municipal sobre o tema.

Contudo, há casos nos quais os pedidos relacionados aos profissionais foram negados pelos tribunais. Em um, não foi deferido pedido relacionado à contratação de profissionais para atuarem em centros de EI sob o fundamento de que não foi apresentada nos autos qualquer prova a respeito desta necessidade; em outros, negaramse pedidos de disponibilização de profissionais para uma creche existente no município e de contratação de novos profissionais sob fundamento de que o Poder Judiciário estaria ferindo o princípio da separação dos poderes, pois entraria no âmbito da discricionariedade do Executivo, intervindo no seu juízo de conveniência e oportunidade (MATO GROSSO DO SUL, 2015).

Foi possível identificar, por fim, que mesmo nas decisões em que se determina a contratação de profissionais, capacitação ou formação do corpo docente, não há quaisquer especificações de como a mesma deveria ser cumprida - exceto a informação da necessária realização de concursos públicos -, ainda que a LDB preveja com clareza a formação inicial mínima necessária exigida destes profissionais. Essa informação é importante na medida em que se deixa à Administração Pública a escolha dos meios adequados ao cumprimento das decisões.

\section{NÚMERO DE CRIANÇAS POR ADULTO, POR TURMA E DIMENSÃO MÍNIMA}

A relação da quantidade de crianças por adulto, por turma e por metro quadrado não está positivada em nenhuma norma legal de âmbito federal. Ressalte-se que há previsão da quantidade de crianças por professor, de acordo com sua idade, ${ }^{4}$ no Parecer no $20 / 09$ do CNE/ CEB (Conselho Nacional de Educação/ Câmara de Educação Básica). 
Há nove casos que, de alguma maneira, tratam destas condições de oferta. Em parte deles, os tribunais apenas mantiveram as determinações constantes nas decisões de primeira instância relacionadas ao número máximo de crianças por adulto, por turma ou a dimensão mínima, sem maiores especificações. Nessas decisões, o fundamento para a manutenção foi relacionado de forma geral ao direito à EI. Em alguns casos, utilizou-se de normas editadas pelos conselhos municipal ou estadual de educação sobre o assunto, ou, ainda, em leis estaduais ou municipais que apresentam especificações relacionadas ao tema.

Observou-se, nessa categoria, que parte das decisões considerava as resoluções editadas pelos conselhos municipais ou estaduais de educação, algo que ainda não havia sido encontrado em decisões relacionadas a diferentes condições de oferta. Este achado é relevante na medida em que demonstra que os Tribunais têm se atentado às regulamentações sobre o tema, mesmo que em âmbito municipal e estadual, o que comprova a relevância de sua juridificação para que possa ser exigida enquanto medida de qualidade da oferta da EI. Isto porque, como ressaltado por Ximenes (2014, p. 67), a juridificação é importante para "o reconhecimento de novos direitos, na ampliação de sua realização e no fortalecimento de sua justiciabilidade". Desta forma, a previsão legal do número máximo de crianças por adulto, por turma e a dimensão mínima necessária para atendimento das crianças na EI tornaria estas condições de oferta mais facilmente exigíveis do Estado.

\section{JORNADA E CARGA HORÁRIA}

A LDB prevê que o atendimento à EI poderá se dar em turno parcial de, no mínimo, 4 horas diárias, ou jornada integral de 7 horas diárias, compondo carga horária mínima de 800 horas anuais, divididas em 200 dias letivos. (BRASIL, 1996). Essa mesma previsão em relação à jornada pode ser encontrada nas Diretrizes Curriculares Nacionais para a Educação Infantil, revisadas pela Resolução $n^{\circ}$ 05/2009 do CNE/CEB. O PNE prevê, ainda, o estímulo à oferta em tempo integral a todas as crianças atendidas nessa etapa da educação, bem como a oferta da educação em tempo integral em, no mínimo, $50 \%$ das escolas públicas de forma a atender, no mínimo, 25\% dos alunos da educação básica (BRASIL, 2014).

Em algumas decisões, há determinações relacionadas à jornada e carga horária para a oferta da EI. Contudo, percebe-se 
que os tribunais aliam a carga horária à jornada, estabelecendo carga horária diária mínima a ser cumprida. Foram encontradas 22 decisões em que esse tema, de alguma forma, é abordado.

Há casos em que apenas se determina a oferta de vagas na EI, com base nesse direito, em período ou tempo integral, sem discutir quaisquer fundamentos relacionados a esta condição de oferta. Contudo, em algumas decisões são agregados pelo órgão julgador outros fundamentos que aprofundam a discussão em relação à oferta de vagas em tempo integral, quais sejam: possibilidade de cumprimento de uma das finalidades da LDB, o desenvolvimento integral da criança; que a oferta deve observar a carga horária prevista na LDB; que é necessária para garantir o trabalho dos pais e, portanto, a subsistência da família.

Contudo, há casos em que esta condição de oferta foi negada. Os fundamentos apresentados para a negativa são, em geral, de que a LDB não exige o cumprimento de jornada integral e que a EI não pode ser vista apenas sob uma concepção assistencialista, motivo pelo qual não é viável opor à criança uma jornada excessiva, que impeça suas necessidades de convivência familiar; que não se deve visar o atendimento das necessidades dos pais, mas sim o melhor atendimento aos interesses das crianças.

\section{CURRÍ́CULO}

A LDB prevê os componentes curriculares obrigatórios nas diversas etapas da educação, entre elas, na EI. Em seu art. 26, a referida lei disciplina que o currículo da EI, bem como do ensino fundamental e médio, deve ter uma base nacional curricular comum "a ser complementada, em cada sistema de ensino e em cada estabelecimento escolar, por uma parte diversificada, exigida pelas características regionais e locais da sociedade, da cultura, da economia e dos educandos" (BRASIL, 1996). Saliente-se que, no ano de 2017, o MEC entregou ao CNE uma segunda versão da base nacional curricular comum, contemplando componentes da EI, que foi homologada no dia 20 de dezembro daquele ano

Foi identificado um caso no qual se discutiu a obrigatoriedade de oferta da disciplina de educação física na EI. O estado do Rio de Janeiro ofertava EI em determinado município sem que o componente curricular de educação física estivesse contemplado no currículo, sob o argumento de que, por não se tratar de etapa educacional que compunha sua competência administrativa constitucional, não possuía obrigatoriedade em ofertar referida disciplina. O tribunal manteve a sentença que condenou o estado a ofertar referido componente 
curricular nas unidades de EI por ele mantidas, sob o fundamento de que o mesmo é obrigatório na educação básica, da qual a EI é etapa integrante. Portanto, embora o estado não seja obrigado a ofertar a EI, ao fazê-lo deveria também garantir a disciplina de educação física às crianças que a frequentam (RIO DE JANEIRO, 2006).

\section{APOIO TÉCNICO E FINANCEIRO DOS ESTADOS}

O apoio técnico e financeiro dos estados e da União aos municípios para a oferta da EI é disciplinado em diversas normas legais, tais como o art. $211 \mathrm{da} \mathrm{CF} / 88$, art. $8^{\circ}, \$ 1^{\circ}$ e $9^{\circ}$, III, da LDB e 54 do ECA. Foi estabelecida como uma categoria de condições de oferta ante a especificidade da decisão encontrada sobre o tema, que aponta a impossibilidade do município ofertar, sozinho, a EI à população, como se verá adiante. A CF/88 prevê, ainda, que a competência para a oferta da EI é dos municípios, nos termos do art. 30, VI (BRASIL, 1988). Contudo, é necessário esclarecer que, ainda que esta etapa da educação seja de competência dos municípios, a previsão constitucional esclarece que a mesma deve ser realizada com a cooperação técnica da União e dos Estados, bem como que é competência comum da União proporcionar os meios de acesso à educação (art. 23, V) (BRASIL, 1988).

O art. 211 da CF/88 prevê o regime de colaboração entre União, Estados e Municípios para a organização de seus sistemas de ensino, o que foi reforçado pelo art. $7^{\circ}$ do PNE de 2014, que prevê especificamente, em seu $\int 5^{\circ}$, "Será criada uma instância permanente de negociação e cooperação entre a União, os Estados, o Distrito Federal e os Municípios" e, no $₫ 6^{\circ}$, a "instituição de instâncias permanentes de negociação, cooperação e pactuação em cada Estado" (BRASIL, 2014). Portanto, embora dos resultados da presente pesquisa seja possível extrair que quase a totalidade das demandas são propostas exclusivamente contra os municípios, a União e os Estados também possuem dever no que se refere à oferta da EI, ainda que mediante apoio aos municípios.

Há decisões em ações coletivas perante os Tribunais de Justiça no Brasil em que se discute a necessidade de integrar a União e/ou os estados nas ações coletivas ajuizadas contra os municípios exigindo o direito à EI. Contudo, essas decisões não foram selecionadas por tratar muito mais da questão processual a respeito da existência do litisconsórcio passivo necessário do que do direito à EI, já estando pacificado que as ações podem ser propostas apenas contra os municípios, sem configurar qualquer nulidade. 
Todavia, identificou-se um caso em que o estado compõe o polo passivo de ação civil pública proposta pelo Ministério Público, tendo sido condenado em primeira instância a ofertar vagas de EI no município, além de prestar assistência técnica e financeira. A decisão foi mantida pelo Tribunal, sob o fundamento de que de acordo com os artigos $211, \int \$ 2^{\circ}$ e $3^{\circ}$ e art. 208 , IV e $\$ 1^{\circ}$, da CF $/ 88$ a organização dos sistemas de ensino é comum aos entes federados, bem como que, de acordo com o texto constitucional, a EI incumbe também aos estados, uma vez que a atuação dos municípios é apenas prioritária e não exclusiva. Consta ainda da decisão que é necessário que a população seja provida, devendo os entes federados atuarem conjuntamente para a efetivação do direito à EI. Que é função de todos os entes a universalização do ensino obrigatório, nos termos da CF/88 e do ECA. E, por fim, que o direito à EI configura-se em direito fundamental, sendo dever de todos os entes e, em especial, do estado do Pará, assegurar sua oferta, em regime de colaboração (PARÁ, 2010).

A relevância do caso analisado, além de sua fundamentação, reside na previsão constante da decisão da responsabilidade do estado ofertar a EI, em regime de colaboração e prestando o apoio técnico e financeiro, pois não poderia a população ficar desatendida, bem como que o atendimento deveria se dar mediante garantia do padrão de qualidade. Houve condenação conjunta do estado e do município na oferta da EI, sendo o estado do Pará expressamente condenado a prestar o serviço de pré-escola às crianças a partir de cinco anos, mantendo um total de 14.283 vagas em funcionamento, um precedente que não foi observado em nenhum outro caso dentre todos os dados coletados nesta pesquisa.

\section{OUTRAS CONDIÇÕES DE OFERTA}

Foram identificados dois casos nos quais se abordaram outras condições de oferta que não integram nenhuma das demais categorias analisadas. Nesses dois casos, verifica-se que as condições de oferta foram determinadas de uma forma muito singela, sem quaisquer especificações e fundamentações por parte do Poder Judiciário. Em um deles, determinou-se ao município que ofertasse vagas em EI em estabelecimentos adequados às condições de higiene e segurança, pois há notícia nos autos de que as crianças recebiam atendimento de forma insuficiente e irregular no que se refere a ambos os aspectos (SÃO PAULO, 2012).

No outro, o município fora condenado em primeira instância a ofertar vagas em EI com a prática de atividades administrativas, 
sociais, psicopedagógicas, nutricionais e sanitárias, dentre outras condições de oferta existentes na decisão. Esta decisão foi reformada sob o fundamento de que configuraria ofensa ao princípio da separação dos poderes (SÃ̃ PAULO, 2010).

\section{NEGATIVA DO ACESSO FUNDAMENTADA NA REDUC̣ÃO DA QUALIDADE DA EI}

Durante a coleta e análise de dados encontraram-se três decisões nas quais se nega a ampliação das redes ou da abertura de vagas nessa etapa da educação sob o fundamento de que incluir mais crianças irá reduzir a qualidade do serviço ofertado. Em trabalho anterior, Silveira (2014) já indicara que, entre os principais argumentos levantados pela Administração visando a negativa da oferta de vagas na EI, estariam aqueles que relacionavam a inclusão de mais crianças à diminuição da qualidade do serviço.

Embora, como já indicado, excluiu-se da análise qualitativa de conteúdo das decisões aquelas que versavam apenas sobre o acesso, esses casos demonstraram-se relevantes na medida em que indicavam o acesso como limitador da oferta de uma educação de qualidade. Portanto, nesses casos o acesso não é considerado como elemento necessário à garantia da qualidade da EI. Assim percebe-se que ainda há, em pelo menos dois Tribunais de Justiça do Brasil - TJMT e TJPR -, o entendimento de que a ampliação do acesso reduz a qualidade. Percebe-se, portanto, que há casos nos quais os Tribunais de Justiça do Brasil não consideram o acesso como componente da qualidade.

\section{SÍNTESE DAS DECISÕES DOS TRIBUNAIS DE JUSTIC̣A DO BRASIL EM AÇÕES COLETIVAS NAS QUAIS SE DISCUTEM CONDIÇÕES DE OFERTA DA EI}

Inicialmente, verifica-se que dos 22 Tribunais de Justiça do Brasil que contam com decisões em ações coletivas em que o direito à EI é exigido, em 18 encontram-se decisões em que se discutem também condições de oferta. O gráfico 2 abaixo demonstra a quantidade dessas decisões em cada tribunal, sendo que o maior número de casos é encontrado no TJMG, seguido pelo TJSC, TJSE, TJSP, TJRS, TJPR e TJMT. À exceção do TJSE, no qual a maioria das decisões em que se exige a EI por meio de medidas coletivas requerem condições de oferta, percebe-se que os tribunais nos quais se discutem condições de oferta estão mais concentrados nas regiões sudeste e sul.

O gráfico 2 demonstra, ainda, a quantidade de casos nos quais as condições de oferta são deferidas ou indeferidas de acordo com os tribunais, verificando-se que, proporcionalmente à quantidade de 
casos, o TJAC, TJMS, TJSP e TJMG parecem ser os tribunais mais resistente às causas que discutem o tema, enquanto a totalidade dos casos discutidos pelos TJRJ, TJTO, TJAL, TJES, TJGO, TJMA, TJPA e TJRN foram de decisões que deferem condições de oferta nas ações coletivas que exigem o direito à EI.

GRÁFICO 2. Decisões em ações coletivas nas quais se discutem condições de oferta da El segundo sua localização nos Tribunais de Justiça do Brasil (2006-2016)

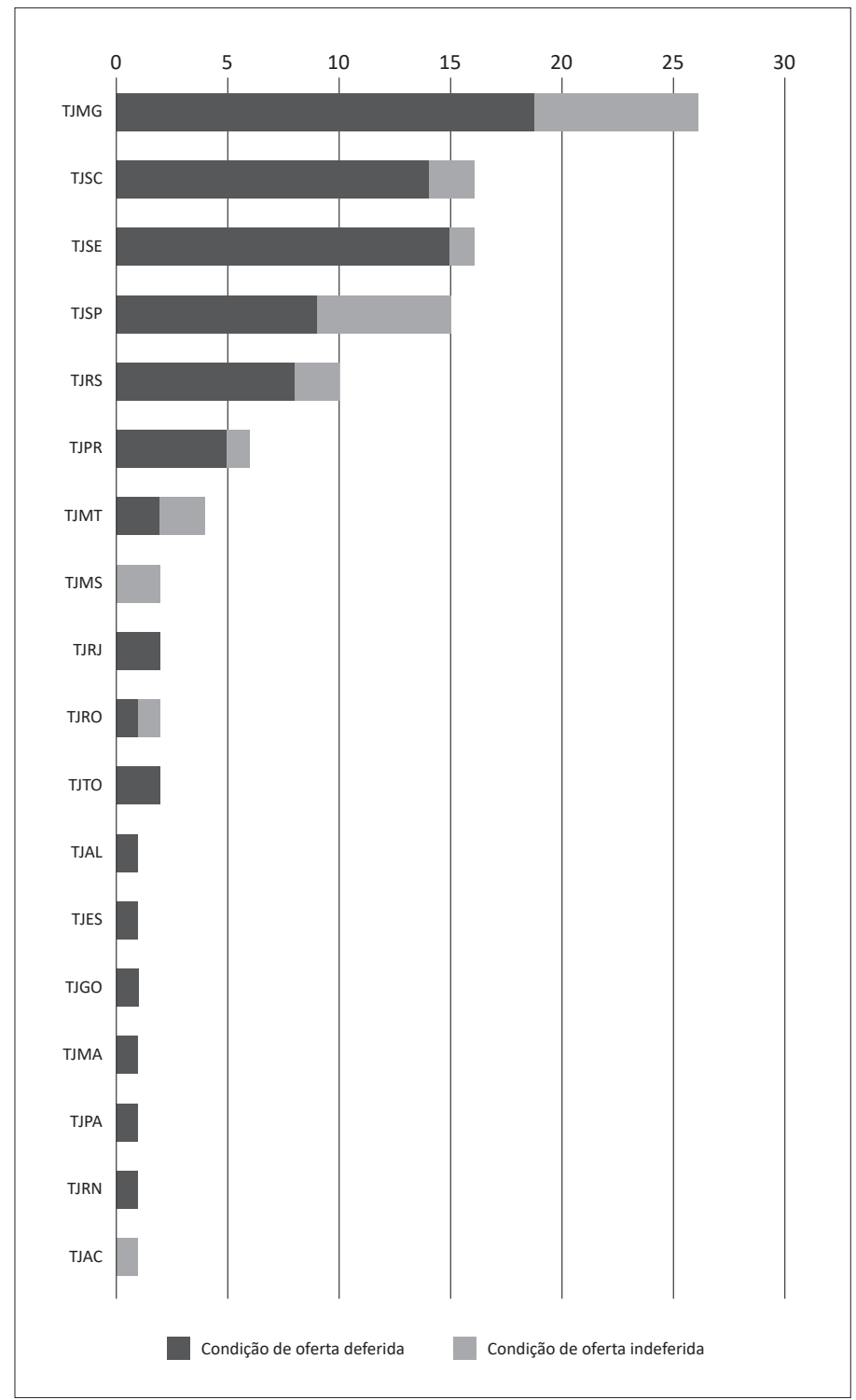

Fonte: Elaborado com base em pesquisa realizada nos Tribunais de Justiça do Brasil (2017). 
Da análise do conteúdo das decisões selecionadas, percebese que há casos em que as condições de oferta da EI são deferidas, quando requeridas em ações coletivas, assim como casos nos quais as mesmas são indeferidas. Em 76\% das decisões analisadas, as condições de oferta são deferidas pelos tribunais, o que mostra uma tendência do Poder Judiciário em reconhecê-las como necessárias à garantia do direito à EI.

O gráfico 3 a seguir demonstra a distribuição temporal dessas decisões, indicando o deferimento ou indeferimento das condições de oferta em cada ano. Verifica-se que, à exceção dos anos de 2010 e 2016, aparentemente o deferimento de condições de oferta vem acompanhando o crescimento das demandas que discutem essas questões, ano a ano, não se identificando uma relação direta entre o maior ou menor reconhecimento do direito em virtude de sua distribuição temporal. Analisando-se o conteúdo dessas decisões, verificou-se que a maioria absoluta das decisões nas quais houve o indeferimento das condições de oferta no ano de 2010, referemse a casos em que se discute construção ou infraestrutura. Já, no ano de 2016, as condições de oferta negadas tratam de jornada ou fornecimento de vagas próximas à residência das crianças ou mediante oferta de transporte público. 
GRÁFICO 3. Distribuição temporal das decisões dos Tribunais de Justiça do Brasil, segundo o deferimento das condições de oferta da El (2006-2016)

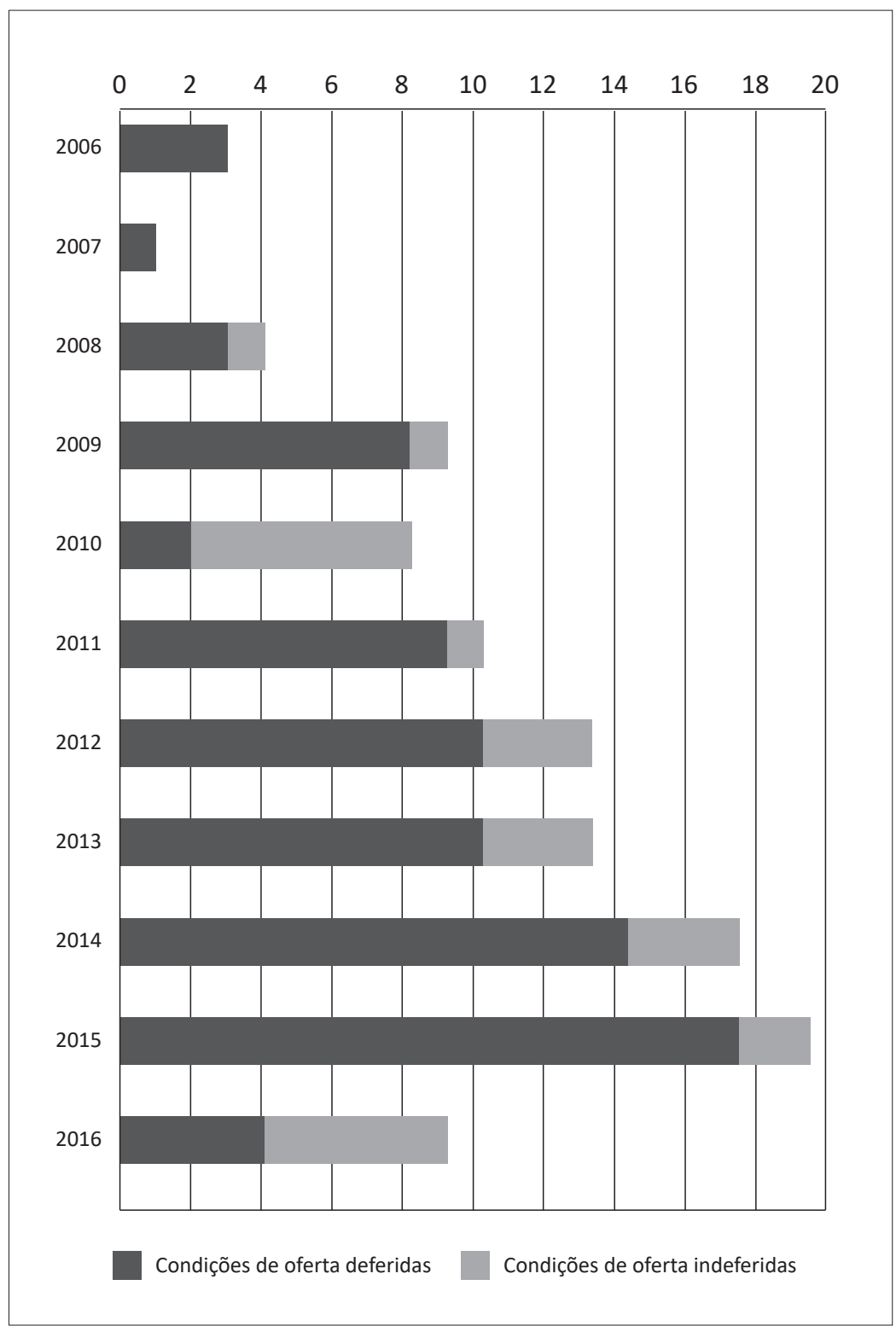

Fonte: Elaborado com base em pesquisa realizada nos Tribunais de Justiça do Brasil (2017).

Sendo assim, demonstra-se relevante, ainda, verificar dentre as categorias aquelas nas quais há maior aceitabilidade pelos Tribunais de Justiça do Brasil, o que pode ser verificado pela análise do gráfico 4 a seguir. 
Percebe-se que os pedidos relacionados à construção de novas unidades, jornada e carga horária e de infraestrutura recebem mais resistência por parte dos tribunais pátrios, sendo que há uma maior facilidade de se obter o deferimento dos pedidos relacionados à oferta de vagas próxima à residência das crianças ou mediante a garantia do transporte público. Percebe-se que estes casos possuem uma maior proximidade com as demandas por acesso, cujo reconhecimento judicial já está pacificado.

GRÁFICO 4. Decisões dos Tribunais de Justiça do Brasil em relação ao deferimento ou indeferimento das condições de oferta de acordo com as categorias (2006-2016)

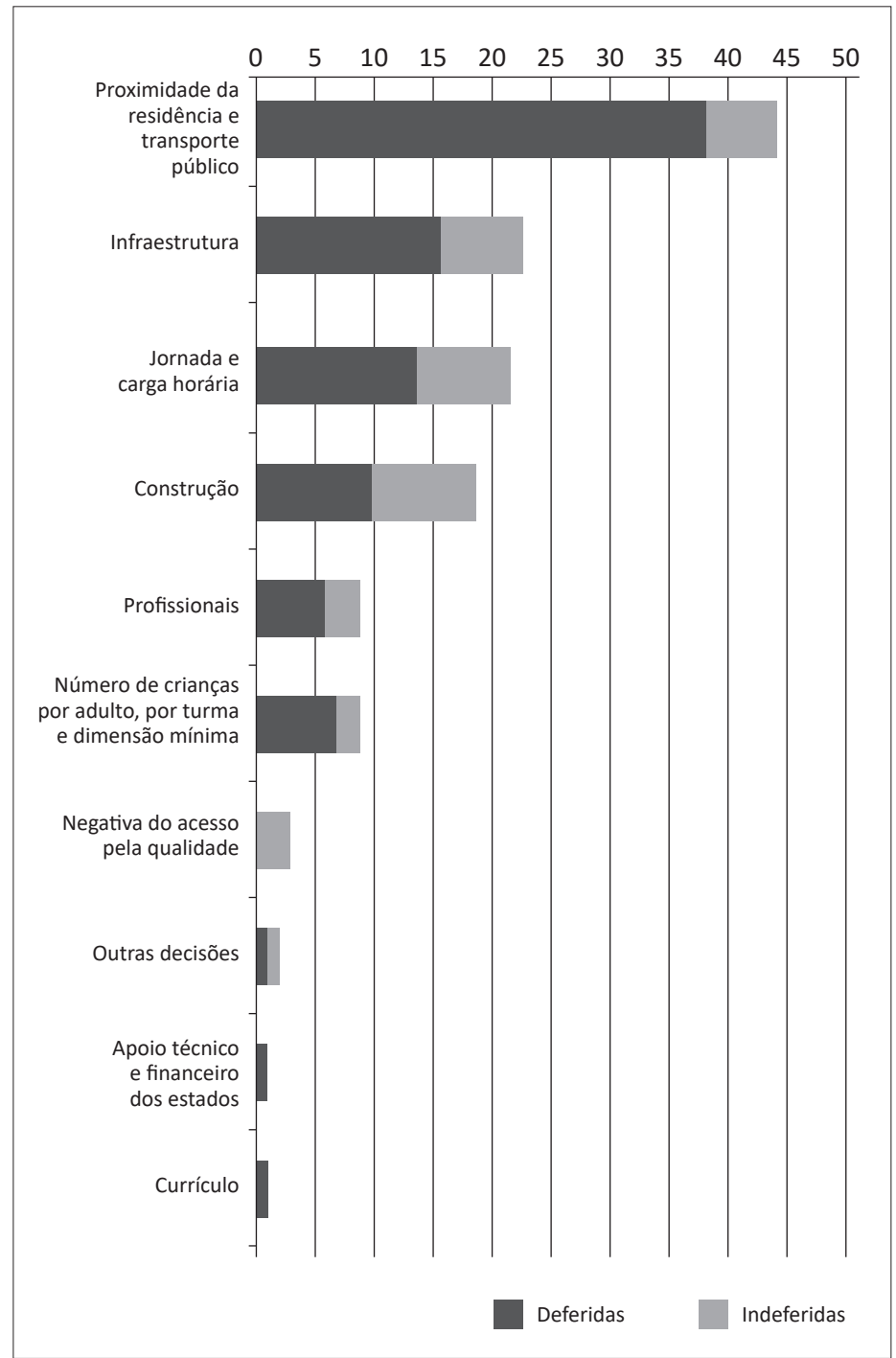

Fonte: Elaborado com base em pesquisa realizada nos Tribunais de Justiça do Brasil (2017). 
Da análise qualitativa das decisões foi possível identificar seus fundamentos. Em grande parte delas, os fundamentos utilizados pelos tribunais para o deferimento ou indeferimento das condições de oferta são os mesmos relacionados à concessão do acesso: o dever do Estado para com a EI, assegurado constitucionalmente; ou os princípios da separação dos poderes e a teoria da reserva do possível, respectivamente. Contudo, há casos nos quais se verificou a existência, nas decisões, de argumentações diferenciadas em relação a cada uma das categorias.

Enquanto os fundamentos para o deferimento das condições de oferta possuem certa variedade e analisam especificamente os requerimentos efetuados, os fundamentos para o indeferimento, em geral, são os mesmos utilizados para a negativa do acesso à EI, apontados, por exemplo, no trabalho de Silveira (2013) e de Scaff e Pinto (2016), relacionados principalmente à ofensa ao princípio da separação dos poderes ou à indisponibilidade financeira do ente para a promoção do direito.

Para o deferimento das condições de oferta, muitas decisões têm fundamento no ECA e algumas acrescentam fundamentos existentes na LDB, que ainda é pouco utilizada e explorada pelos tribunais nos casos em que as condições de oferta são analisadas. Em alguns poucos casos foi possível observar que foram adotados como fundamentos, leis estaduais, municipais e resoluções dos conselhos estaduais e municipais de educação, sendo que em nenhum deles foi utilizada normativas expedidas pelo CNE.

Foi possível identificar casos em que as condições de oferta são expressamente relacionadas, pelos tribunais, como necessárias à garantia da EI de qualidade. Esses precedentes permitem concluir que o Poder Judiciário tem reconhecido, ainda que de forma incipiente, que apenas o acesso não garante o direito à EI.

Por outro lado, os fundamentos para a negativa das condições de oferta também não se diferenciam daqueles alegados pelos municípios e, em alguns casos, aceitos pelos tribunais para a negativa do acesso. Contudo, no caso das condições de oferta, há uma maior discussão a respeito da discricionariedade administrativa, uma vez que em algumas decisões a condição aparece atrelada aos meios que deverão ser escolhidos pela Administração, segundo seu juízo de conveniência e oportunidade, para dar atendimento ao fim constitucional de oferta da EI.

\section{CONSIDERAC̣̃̃ES FINAIS}

Por meio da coleta realizada neste trabalho, verificou-se a existência de 107 decisões proferidas pelos Tribunais de Justiça do 
Brasil em ações coletivas nas quais se exige o direito à EI que, em determinada medida, fazem discussões relacionadas às condições de oferta. Esse achado indica que tem sido levado ao conhecimento dos Tribunais de Justiça do Brasil um considerável número de demandas que não buscam apenas o acesso à EI, mas também que a ampliação das vagas se dê com alguma medida de qualidade.

Da análise do conteúdo destas decisões e, em especial, da fundamentação encontrada, percebe-se que o Poder Judiciário tem, em grande parte das vezes, observado a existência das previsões legais positivadas no ordenamento jurídico para a análise e deferimento das condições de oferta na EI. No entanto, a compreensão da qualidade da educação como princípio de direito considera, como visto, não apenas as previsões legais, mas a busca de tudo o que pode ser considerado como necessário à sua garantia, de forma ampla e maximizada. Portanto, embora se compreenda que não são todas as dimensões de qualidade que devam ser juridificadas (XIMENES, 2014), o exercício da função jurisdicional pelo Poder Judiciário, de julgar a lei, reforça a importância de juridificar, em determinada medida, o que se entende por qualidade (OLIVEIRA; ARAÚJO, 2005). Nesse caso, demonstrase relevante a previsão legal dos insumos indispensáveis à garantia desse direito, como define a LDB e o CAQ, previsto no PNE.

Embora nos casos analisados verifique-se uma maior propensão do Poder Judiciário na concessão do direito relacionado às condições de oferta da EI em relação a questões já positivadas em normas legais, há casos em que, embora não haja previsão legal constituindo o dever do Estado - como é o caso da oferta em tempo integral - se defere o direito independente da discussão a respeito da juridificação da condição de oferta pleiteada. Desta forma, se o Poder Judiciário tem restrito sua análise às questões já juridificadas, poderia se falar em judicialização nos casos ora abordados?

Partindo-se do pressuposto que a judicialização é o deslocamento das decisões tomadas tradicionalmente pelos Poderes eleitos para o Poder Judiciário (BARROSO, 2009; SILVEIRA, 2013), a aplicação das previsões legais, sem que haja deslocamento de decisões políticas para esse poder, não se configuraria como judicialização (SOUSA SANTOS, 2011). Porém, em diversos casos analisados, percebe-se um real deslocamento de decisões políticas, como aqueles em que se determina a oferta de vagas em localidades específicas, a ampliação, reforma ou construção de unidades, a contratação de profissionais já aprovados em concurso visando ampliar o atendimento, a determinação de abertura de vagas na EI por um estado e não apenas pelo município, entre outros. Mas, identificaram- 
se casos nos quais se encontra apenas a determinação de atendimento a um direito, como o caso no qual se discute a disciplina de educação física como componente curricular obrigatório da EI.

Reconhecendo-se a existência da judicialização em alguns casos analisados, também chama a atenção a ausência de informações acerca da oitiva de profissionais da área educacional, que pudessem auxiliar nas decisões, como já apontado por Scaff e Pinto (2016) e Silveira (2008). Da mesma forma, não se identificaram fundamentos baseados nas pesquisas realizadas na área educacional. Verifica-se, aí, a falta de diálogo do Poder Judiciário com as produções e os profissionais da área da educação. Esse achado reforça a necessidade de que a formação dos profissionais do direito, em especial dos magistrados, contemple formações especializadas e de forma interdisciplinar, como apontado por Sousa Santos (2011).

Contudo, embora haja um avanço no que se refere à análise de condições de oferta pelos Tribunais de Justiça do Brasil, ainda são restritos os casos nos quais são discutidas. Percebe-se que em sua grande parte tratam de condições de oferta relacionadas a dimensões que possuem maior proximidade com o acesso, como aqueles nos quais se discute a oferta de vagas próxima à residência das crianças ou mediante oferta de transporte público, correspondendo a $41 \%$ das decisões categorizadas, que se trata justamente do tema com maior aceitabilidade pelos tribunais. Nesta seara, não é possível indicar a ocorrência de uma judicialização relevante das condições de oferta da EI, na medida em que são poucos os casos nos quais de fato há uma discussão aprofundada a respeito do tema, em comparação com o universo de demandas coletivas nas quais se exige apenas o acesso à EI, sem a qualificação das condições deste atendimento.

Por outro lado, considerando-se, como já apontado, que o Poder Judiciário julga de acordo com as questões que lhe são apresentadas nos autos, verifica-se a relevância de que pesquisas futuras busquem identificar se os demandantes, nestas medidas, têm incorporado a pauta da qualidade da EI em seus requerimentos de forma relevante. Assim será possível avaliar se as discussões relativas ao tema carecem de uma maior atenção pelos Tribunais de Justiça do Brasil pela ausência de seu aprofundamento em relação ao tema ou em virtude do que lhe é dado conhecer nas demandas que são levadas ao seu conhecimento.

\section{REFERÊNCIAS}

ABRAMOVICH, V. Linhas de trabalho em direitos econômicos, sociais e culturais: instrumentos e aliados. SUR - Revista Internacional de Direitos Humanos. Ano 2, n.2, p. 188-223, 2005. 
ALAGOAS. Tribunal de Justiça. Agravo de instrumento nº 0803932-44.2014.8.02.0000. Agravante: Município de Igaci. Agravado: Defensoria Pública do Estado de Alagoas. Relator: Domingos de Araújo Lima Neto. Maceió, 18 fev. 2016.

ARAÚJO, F. R. T. Controle judicial de políticas públicas e realinhamento da atividade orçamentária na efetivação do direito à educação: processo coletivo e a cognição do judiciário. 2013. 197 f. Dissertação (Mestrado) - Curso de Direito Negocial, Universidade Estadual de Londrina, Londrina, 2013.

BARROSO, L. R. Judicialização, ativismo e legitimidade democrática. Revista Eletrônica de Direito do Estado, n. 18, abr. 2009. Trimestral. Disponível em: < http://www.oab.org. br/editora/revista/users/revista/1235066670174218181901.pdf>.

BEISEGEL, Celso de Rui. A qualidade do ensino na escola pública. Brasília, Liber Livro Editora, 2006.

BOBBIO, N. A era dos direitos. Rio de Janeiro: Campus, 1992. Tradução de: Carlos Nelson Coutinho.

BRASIL. Constituição (1988). Constituição da República Federativa do Brasil. Brasília, 5 out. 1988.

BRASIL. Lei federal $\mathbf{n}^{\circ} \mathbf{1 3 . 3 0 0}$, de 23 de junho de 2016. Disciplina o processo e o julgamento dos mandados de injunção individual e coletivo e dá outras providências. Brasília: jun. 2016.

BRASIL. Lei federal $\mathrm{n}^{\circ} \mathbf{4 . 0 2 4}$, de 20 de dezembro de 1961. Fixa as diretrizes e bases da educação nacional. Disponível em: < http://www.planalto.gov.br/ccivil_03/leis/L4024. htm>. Acesso em: 14 mai. 2017.

BRASIL. Lei federal $\mathbf{n}^{\mathbf{0}} 7.347$ de 24 de julho de 1985. Disciplina a ação civil pública de responsabilidade por danos causados ao meio-ambiente, ao consumidor, a bens e direitos de valor artístico, estético, histórico, turístico e paisagístico (VETADO) e dá outras providências. Brasil, 1985. Disponível em: <http://www.planalto.gov.br/ccivil_03/leis/L7347orig.htm>. Acesso em: 16 mai. 2017.

BRASIL. Lei federal $\mathbf{n}^{\mathbf{0}} \mathbf{8 . 0 6 9}$, de 13 de julho de 1990. Estatuto da criança e do adolescente. Rio de Janeiro: Imprensa Oficial, 1990.

BRASIL. Lei federal n $^{\circ} 8.078$ de 11 de setembro de 1990. Dispõe sobre a proteção do consumidor e dá outras providências. Brasília, 11 set. 1990b.

BRASIL. Lei $\mathrm{n}^{\circ}$ 11.738, de 16 de julho de 2008. Regulamenta a alínea "e" do inciso III do caput do art. 60 do Ato das Disposições Constitucionais Transitórias, para instituir o piso salarial profissional nacional para os profissionais do magistério público da educação básica. Brasília, 2008b. Disponível em: < http://www.planalto.gov.br/ccivil_03/_ato20072010/2008/lei/111738.htm>. Acesso em: 31 out. 2016.

BRASIL. Lei no 13.105, de 16 de março de 2015. Código de Processo Civil. Brasília, 2015a. Disponível em: <http://www.planalto.gov.br/ccivil_03/_ato2015-2018/2015/lei/113105. htm>. Acesso em: 19 jan. 2016. 
BRASIL. Ministério da Educação. Conselho Nacional da Educação. Parecer CNE/CEB $\mathbf{n}^{\circ}$ 20/2009. Revisão das diretrizes curriculares nacionais para a educação infantil. Brasília: MEC, 2009b.

BRASIL. Ministério da Educação. Secretaria de Educação Básica. Diretrizes curriculares nacionais para a educação infantil. Secretaria de Educação Básica. - Brasilia: MEC, SEB, 2010.

BRASIL. Ministério da Educação. Secretaria de Educação Básica. Parâmetros nacionais de qualidade para a educação infantil. 2006.

BRASIL. Supremo Tribunal Federal. Recurso Extraordinário no 436996. Recorrente: Ministério Público do Estado de São Paulo. Recorrido: Município de Santo André. Relator: Ministro Celso de Mello. Brasília, 26 de janeiro de 2005. Diário de Justiça da União. Brasília, 07 nov. 2005.

CABRAL, K. M. A justiciabilidade do direito à qualidade do ensino fundamental no Brasil. 2008. 195 f. Dissertação (Mestrado) - Curso de Educação, Unesp, Presidente Prudente, 2008.

CAMPOS, M. M.; HADDAD, S. O direito humano à educação escolar pública de qualidade. In HADDAD, S.; GRACIANO, M. A educação entre os direitos humanos. Campinas: Autores Associados, p. 95-125, 2006.

CANELA JUNIOR, O. O orçamento e a "reserva do possível': dimensionamento no controle judicial de políticas públicas. In: GRINOVER, A. P.; WATANABE, K. O controle jurisdicional de políticas públicas. Rio de Janeiro: Forense, $2^{\mathrm{a}}$ ed., 2013.

CURY, C. R. J.; FERREIRA, L. A. M. Justiciabilidade no campo da educação. Rbpae, Goiânia, v. 26, n. 1, p.75-103, jan. 2010. Quadrimestral. Disponível em: < http://seer.ufrgs. br/rbpae/article/viewFile/19684/11467>. Acesso em: 02 jan. 2016.

JACOB, C. A. A. A “reserva do possível”: obrigação de previsão orçamentária e de aplicação da verba. In: GRINOVER, A. P.; WATANABE, K. O controle jurisdicional de políticas públicas. Rio de Janeiro: Forense, $2^{\mathrm{a}}$ ed. p. 237-283, 2013.

LIBERATI, W. D. Conteúdo material do direito à educação escolar. In LIBERATI, W. D. Direito à educação: uma questão de justiça. São Paulo: Editora Malheiros, 2004. P. 121-168.

LOPES, J. R. L. Direito subjetivo e direitos sociais: o dilema do judiciário no estado social de direito. In: FARIA, J. E. (org.). Direitos Humanos, Direitos Sociais e Justiça. São Paulo: Malheiros Editores, 2002.

MACHADO, L. M.; OLIVEIRA, R. P. de. Direito à educação e legislação do ensino. In: WITTMANN, L. C.; GRACINDO, R. G. O Estado da arte em política e gestão da educação no Brasil: 1991 a 1997, Brasília: ANPAE/Campinas: Editora Autores.

MARINHO, C. M. Justiciabilidade dos direitos sociais: análise de julgados do direito à educação sob o enfoque da capacidade institucional. 2009. 120 f. Dissertação (Mestrado) Curso de Direito, Universidade de São Paulo, São Paulo, 2009.

MATO GROSSO DO SUL. Tribunal de Justiça. Agravo de instrumento no 080113078.2012.8.12.0028. Agravante: Município de Bonito. Agravado: Ministério público. Relator: Marco André Nogueira Hanson. Campo Grande 17 nov. 2015. 
MINAS GERAIS. Tribunal de Justiça. Apelação e Reexame Necessário n ${ }^{\circ} 0491248$ 87.2011.8.13.0024. Apelante: Município de Belo Horizonte. Apelado: Ministério público.. Relator: Elias Caminho Sobrinho. Belo Horizonte, 02 ago. 2012.

OLIVEIRA, R. P. Estado e política educacional no Brasil: desafios do século XXI. 2006. 106 f. Departamento de economia e administração escolar. Faculdade de Educação, Universidade de São Paulo, 2006.

OLIVEIRA, R. P.; ARAUJO, G. C. Qualidade do ensino: uma nova dimensão da luta pelo direito à educação. Revista Brasileira de Educação, Rio de Janeiro, n. 28, abr. 2005. Disponível em <http://www.scielo.br/scielo.php?script $=$ sci_arttext\&pid=S141324782005000100002\&lng=pt\&nrm=iso >. Acesso em: 05 ago. 2014.

PANNUNZIO, E. O poder judiciário e o direito à educação. In. RANIERI, N. B. S. Direito à educação: aspectos constitucionais. São Paulo: Editora da Universidade de São Paulo, p. 61-88, 2009.

PIETRO, M. S. Z. Direito administrativo. São Paulo: Atlas, 13ª ed., 2001.

PIOVESAN, F. Direitos sociais: proteção internacional e perspectivas do constitucionalismo latino-americano. In: SAVARIS, J. A.; STRAPAZZON, C. L. (org.). Direitos fundamentais da pessoa humana. Curitiba: Alteridade editora, p. 223-248, 2012.

PARÁ. Tribunal de Justiça. Apelação no 0013441-94.2002.8.14.0301. Apelante: Estado do Pará e Município de Belém. Apelado: Ministério Público. Relatora: Célia Regina de Lima Pinheiro. Belém, 25 fev. 2010.

RIO DE JANEIRO. Tribunal de Justiça. Apelação no 0003889-26.2004.8.19.0063. Apelante: Estado do Rio de Janeiro. Apelado: Ministério Público. Relator: Galdino Siqueira Netto. Rio de Janeiro, 29 nov. 2006.

RIO GRANDE DO NORTE. Tribunal de Justiça. Reexame necessário nº 0000273 71.2007.8.20.0140. Requerente: Ministério público. Requerido: Município de Natal. Relator: Juiz Herval Sampaio. Natal, 27 mai. 2014.

RIZZI, E.; XIMENES, S. B. Litigância estratégica para a promoção de políticas públicas: as ações em defesa do direito à educação infantil em São Paulo. In: FRIGO, D.; PRIOSTE, F.; ESCRIVÃO FILHO, A. S. Justiça e direitos humanos: experiências de assessoria jurídica popular. Curitiba: Terra de Direitos, p. 105-127, 2010.

SÃO PAULO. Tribunal de Justiça. Apelação e reexame necessário no 3001533 79.2013.8.26.0262. Apelante: Prefeitura municipal de Itaberá. Requerido: Ministério Público. Relator: Antonio Celso Faria. São Paulo, 26 ago. 2015.

SÃO PAULO. Tribunal de Justiça. Apelação e reexame necessário no 0119871 78.2010.8.26.0000. Requerente: Município de Jaú. Requerido: Promotor de justiça da vara da infância e juventude de Jaú. Relator: Eduardo Gouvêa. São Paulo, 14 jun. 2010.

SÃO PAULO. Tribunal de Justiça. Embargos de declaração em reexame necessário $\mathrm{n}^{\circ}$ 0127996-60.2009.8.26.0003. Embargante: Município de São Paulo. Embargado: Ministério Público. Relator: Eduardo Gouvêa. São Paulo, 04 abr. 2011. 
SCAFF, E. A. S.; PINTO, I. R. R. O Supremo Tribunal Federal e a garantia do direito à educação. Revista Brasileira de Educação. Rio de Janeiro, v. 21, n. 65, p. 431-454, jun. 2016.

SILVA, E. P. I. D. Os efeitos da atuação do sistema de justiça nas políticas de educação infantil: estudo de caso no município de Araucária/Pr. Dissertação (mestrado). - PósGraduação em Educação da Universidade Federal do Paraná. Curitiba, 2016.

SILVEIRA, A. D. A exigibilidade do direito à educação básica pelo Sistema de Justiça: uma análise da produção brasileira do conhecimento. RBPAE, Porto Alegre, v. 24, n. 3, p. 537-555, dez. 2008.

SILVEIRA, A. D. Conflitos e consensos na exigibilidade judicial do direito à educação básica. Educ. Soc., [s.l.], v. 34, n. 123, p.371-387, jun. 2013. FapUNIFESP (SciELO). DOI: 10.1590/s0101-73302013000200003. Disponível em: < http://www.scielo.br/scielo. php?script=sci_arttext\&pid=S0101-73302013000200003 >. Acesso em: 09 jan. 2016.

SILVEIRA, A. D. Exigibilidade do direito à educação infantil: uma análise da jurisprudência. In: SILVEIRA, A. D.; GOUVEIA, A. B.; SOUZA, A. R. Conversas sobre políticas educacionais. Curitiba: Appris, p. 167-188, 2014.

SILVEIRA, A. D. O direito à educação de crianças e adolescentes: análise da atuação do Tribunal de Justiça de São Paulo (1991-2008). 2010. 303 f. Tese (Doutorado) - Faculdade de Educação da Universidade de São Paulo, São Paulo, 2010.

SILVEIRA, A. D. Possibilidades e limites da judicialização da educação: análise do sistema de justiça do Paraná. Curitiba: UFPR, 2015.104 páginas. Relatório técnico.

SOUSA SANTOS, B. Para uma revolução democrática da justiça. São Paulo: Cortez, 2011.

TELLO, C. Los objetos de estudio de la política educativa: três argumentaciones epistemológicas para su análisis. In TELLO, C. Los objetos de estudio de la política educativa: hacia uma caracterización del campo teórico. Buenos Aires: Autores de Argentina, 2015.

VICTOR, R. A. Judicialização de políticas públicas para a educação infantil: características, limites e ferramentas para um controle judicial legítimo. São Paulo: Saraiva, 2011.

XIMENES, S. B. Direito à qualidade na educação básica: teoria e crítica. São Paulo: Quartier Latin, 2014.

XIMENES, S; GRINKRAUT, A. Acesso à educação infantil no novo PNE: parâmetros de planejamento, efetivação e exigibilidade do direito. Cadernos CENPEC. São Paulo, v. 4, n. 1, p. 78-101, jun. 2014.

ZABALZA, M. A. Qualidade em educação infantil. Porto Alegre: Artmed, 2007.

\section{NOTAS}

${ }^{1} \mathrm{~A}$ ação civil pública é o instrumento processual previsto para a proteção de interesses difusos e coletivos, nos termos do art. 129, III da CF/88 (BRASIL, 1988) que, dentre outros assuntos, versem sobre direitos da infância e adolescência, nos termos do art. 201, V, do ECA (BRASIL, 1990a). 
${ }^{2} \mathrm{O}$ mandado de segurança é a ação proposta para proteger direito líquido e certo de seu titular, nos termos do art. $5^{\circ}$, LXIX da CF/88, podendo ser impetrado coletivamente nos termos do art. $5^{\circ}$, LXX do mesmo diploma legal (BRASIL, 1988).

${ }^{3}$ É a ação cabível "sempre que a falta de norma regulamentadora torne inviável o exercício dos direitos e liberdades constitucionais e das prerrogativas inerentes à nacionalidade, à soberania e à cidadania“" (art. 5 ${ }^{\circ}$ LXXI da CF/88) (BRASIL, 1988). Pode ser considerada um instrumento de tutela dos direitos coletivos na medida em que, sanada a mora legislativa pelo Poder Legislativo, a ação surtirá efeitos para toda a coletividade e não apenas para a parte de propôs a demanda.

${ }^{4}$ Qual seja, de seis a oito crianças por professor no caso de crianças de zero e um ano, quinze crianças por professor no caso de crianças de dois e três anos e vinte crianças por professor no caso de crianças de quatro e cinco anos.

Submetido: $23 / 12 / 2017$

Aprovado: $14 / 05 / 2018$

Contato:

Rua Rio Grande do Sul, no 1581

Curitiba $\mid$ PR |Brasil

CEP 80.630-090 